\begin{tabular}{|c|c|c|}
\hline EREM 74/1 & \multicolumn{2}{|c|}{ Waste as Energy Source in EU Action Plan for the Circular Economy } \\
\hline $\begin{array}{l}\text { Journal of Environmental Research, } \\
\text { Engineering and Management }\end{array}$ & Received 2018/01 & Accepted after revision 2018/02 \\
\hline $\begin{array}{l}\text { pp. } 43-49 \\
\text { DOl 10.5755/j01.erem.74.1.19779 } \\
\text { (C Kaunas University of Technology }\end{array}$ & \multicolumn{2}{|c|}{ Crossef http://dx.doi.org/10.5755/j01.erem.74.1.19779 } \\
\hline
\end{tabular}

\title{
Waste as Energy Source in EU Action Plan for the Circular Economy
}

\section{Arina, R. Bendere}

Institute of Physical Energetics, Latvia, LV-1006, Riga, 11 Krivu st.

Corresponding author: bendere@edi.lv

Institute of Physical Energetics, Latvia, LV-1006, Riga, 11 Krivu st.

Investigations present that changes in municipal solid waste composition and properties correlate with the size and density of the municipal solid waste type, that mechanical pre-treatment including separation by weight and size can be useful for preparation of refuse derived fuel (RDF) material and solid recovered fuel (SRF) used for energy recovery. The authors determine the parameters of separated components of the coarse fraction (lower heating value, moisture, ash content, carbon, nitrogen, hydrogen, sulphur, chlorine, and metals), and assess their viability for the preparation of alternative fuel.

Keywords: waste to energy, circular economy, waste characterisation.

\section{Introduction}

Closing the loop - a European Union (EU) action plan for the Circular Economy for the first time was proposed by the European Commission to the European Parliament in December 2015 (EC, 2017a). Now the European Commission has adopted the Circular Economy Package, which includes revised legislative proposals on waste (EPRS, 2016). The legislative proposals on waste, adopted together with the action plan, include long-term targets to reduce landfilling and to increase preparation for reuse and recycling of key waste streams such as municipal waste and packaging waste:

the EU target for recycling $65 \%$ of municipal waste by 2030 ;

the EU target for recycling $75 \%$ of packaging waste by 2030 ;

a binding landfill target to reduce landfill to the maximum of $10 \%$ of municipal waste by 2030 ;

a ban on landfilling of separately collected waste and main tools how to reach those targets. 
When waste cannot be prevented or recycled, recovering its energy content is in most cases preferable to landfilling it, in both environmental and economic terms. 'Waste to energy' can, therefore, play a role and create synergies with the EU energy and climate policy, but guided by the principles of the EU waste hierarchy (EC, 2017b).

The use of separated organic part as a fuel can be considered as one of the solutions to reduce the amount of landfilled waste. Scientific research on alternative and renewable resources, including the use of waste for energy production, has over the past 15 years been developing rapidly worldwide (Beckmann et al., 2009; Sharma and McBean, 2009; Pohl et al., 2010; Rotter, 2011; Vounatsos, 2012). Investigations present that changes in municipal solid waste composition and properties correlate with the size and density of the municipal solid waste type, that mechanical pre-treatment including separation by weight and size can be useful for preparation of refuse derived fuel (RDF) and solid recovered fuel (SRF) material used for energy recovery.

Solid recovered fuel is fuel produced from non-hazardous waste in accordance with EU standards for SRF, especially EN15359. It is typically produced from municipal solid waste (MSW), industrial and commercial waste or construction and demolition waste (C\&DW). RDF is a non-defined term and refers to waste that has not undergone proper processing and is not standardised; meanwhile, SRF is sampled and tested according to EU standards (ERFO, 2017).

The objective of the report is to evaluate the mechanical pre-treatment technology for unsorted municipal solid waste in Latvia and opportunities for the preparation of alternative fuel as RDF or SRF by carrying out the analysis of waste composition and properties. The authors determine the parameters of separated components (lower heating value, moisture, ash content, carbon, nitrogen, hydrogen, sulphur, chlorine, and metals), and assess their viability for the preparation of alternative fuel.

\section{Materials and methods}

Since municipal solid waste including household waste is heterogeneous, selective waste sampling was used to obtain a reliable sample that would be representative of the average waste composition: each of the random truckloads specifically selected from known waste producers in a specific territory was selected at a landfill in a specific waste accumulation period. For samples taken selectively, it is considered that these samples are fully representative of the population, and the samples include all types of waste characteristic of the specific population. The waste sampling method was appropriate for the assessment of the morphological composition of municipal solid waste and was tested using standards LVS EN 14899:2011; LVS CEN/ TR 15310-1:2007 (Arina and Orupe, 2012). The samples were taken during the four seasons analysing the waste collection routes so as to select a waste load (3 loads) that would be representative of the average waste composition in the territory. Each load was weighed and a representative waste sample was taken from each load with the grab method - approximately $20 \%$ of the load. Each sample was screened for an experimental study in special movable (reciprocating motion) screening equipment that consists of three screens placed horizontally. The screen mesh size (d) of the upper screen is $300 \times 300 \mathrm{~mm}$, the middle screen is $150 \times 150 \mathrm{~mm}$, and the bottom screen is $70 \times 70 \mathrm{~mm}$.

The experimental truckloads of the collected municipal waste were treated using two different separation lines: the linear star screen and the rotating drum screen sorting line (Arina and Orupe, 2013). There are facilities for mechanical shredding, screening and separation of metal in a mechanical pre-treatment centre using linear star screen equipment. The separation and reloading waste station with a rotating drum screener is equipped with a mechanical pre-shredder, a drum screener, a magnetic separator of metal, a manual sorting line, and a cutting mill.

The method of waste sampling after the separation of waste using mechanical sorting lines was selected in order to study the quantity, composition and properties of the sorted waste fractions, to assess their viability for RDF or SRF production.

To predict the waste composition after the use of waste screening equipment and to recover secondary-use materials and materials for RDF or SRF production, the following parameters for examples of the 
coarse fraction from both lines were determined using the standards:

moisture content (\%) - LVS EN 15414-3:2011;

net calorific value $\left(\mathrm{MJ}^{*} \mathrm{~kg}^{-1}\right)$ - LVS EN 15400:2011;

chlorine content (\%) - LVS EN 15408:2011;

sulphur content (\%) - LVS EN 15408:2011;

ash content (\%) - LVS EN 15403:2011;

content of trace elements (As, $\mathrm{Ba}, \mathrm{Be}, \mathrm{Cd}, \mathrm{Co}, \mathrm{Cr}, \mathrm{Cu}$, $\mathrm{Hg}, \mathrm{Mo}, \mathrm{Mn}, \mathrm{Ni}, \mathrm{Pb}, \mathrm{Sb}, \mathrm{Se}, \mathrm{Tl}, \mathrm{V}$ and $\mathrm{Zn}$ ) - LVS EN 15411:2012;

content of major elements (Al, $\mathrm{Ca}, \mathrm{Fe}, \mathrm{K}, \mathrm{Mg}, \mathrm{Na}, \mathrm{P}$, Si, Ti) - LVS EN 15410:2012;

C, H, N content (\%) - LVS EN 15407:2011;

degradable organic carbon (DOC) (\%) - LVS EN 13137:2005.

\section{Results and discussion}

The average data on the content of municipal waste entering two selected sorting lines and, after the sorting, content of coarse fractions are presented in the Table 1.
The pre-treatment using automatic separation lines reduces inorganic components of the coarse fraction as metals, glass and stones and rising organic part as paper, plastics, textile, rubber and leather. The separated fractions have a lower moisture content and a higher heating value. The main properties of coarse fractions from both lines are presented in Table 2 .

Such materials after drying and crashing can be used as an energy source in cement kilns (Table 3 ) or as an energy source for co-incineration plants using biomass and SRF. The nature of SRF is summarised in three parameters: mercury (indicating environmental impact), chlorine (indicating technical behaviour) and net calorific value (indicating the performance) (Table 4).

Additional restrictions limiting the use of waste material for co-incineration kilns are connected with ash content. The ash from biomass burning can be used as a fertiliser, taking into account its content, but adding the waste or RDF, the content of heavy metals and other pollutants can overcome the stated limits. The analyses of ash from separated coarse fractions are presented in Table 5.

\section{Table 1}

Content of municipal solid waste (mass \%) entering the sorting equipment and after treatment by a drum screener and a disc screener (coarse fractions)

\begin{tabular}{|c|c|c|c|c|}
\hline Type of waste & $\begin{array}{l}\text { Entering a drum } \\
\text { screener, } \%\end{array}$ & $\begin{array}{l}\text { Entering a disc } \\
\text { screener, } \%\end{array}$ & $\begin{array}{l}\text { Coarse fraction after pre- } \\
\text { treatment by a drum screener, \% }\end{array}$ & $\begin{array}{l}\text { Coarse fraction after pre- } \\
\text { treatment by a disc screener, } \%\end{array}$ \\
\hline 1 & 2 & 3 & 4 & 5 \\
\hline Biological and fine $(<20 \mathrm{~mm})$ & 59.0 & 69.8 & 26.6 & 3.9 \\
\hline Paper & 5.7 & 2.7 & \multirow{2}{*}{25.8} & \multirow{2}{*}{39.5} \\
\hline Cardboard & 4.3 & 3.4 & & \\
\hline Plastic & 11.5 & 10.1 & 24.8 & 38.7 \\
\hline Textile, rubber, leather & 4.4 & 4.7 & 12.8 & 10.6 \\
\hline Other & 1.7 & 0.8 & 2.7 & 4.1 \\
\hline Wood & 2.2 & 0.25 & 5.3 & 1.1 \\
\hline Glass & 5.5 & 5.4 & 0.4 & 0.2 \\
\hline Metal & 1.3 & 1.3 & \multirow{3}{*}{0.7} & \multirow{3}{*}{1.5} \\
\hline Aluminium & 2.3 & 0.4 & & \\
\hline Tin & 0.3 & 0.4 & & \\
\hline Inert & 1.9 & 0.9 & 1.3 & 0.4 \\
\hline
\end{tabular}




\section{Table 2}

The mean values of the parameters of coarse fractions after a drum screener and a disc screener

\begin{tabular}{l|c|c|c|c|c|c|c|c}
\hline \multicolumn{1}{|c|}{ Fraction } & $\begin{array}{c}\text { Moisture, } \\
\%\end{array}$ & $\begin{array}{c}\mathrm{Q}_{\text {net }} \\
\mathrm{MJ}^{*} \mathrm{~kg}^{-1}\end{array}$ & $\begin{array}{c}\mathrm{Ash}, \\
\%\end{array}$ & $\begin{array}{c}\mathrm{Cl}, \\
\%\end{array}$ & $\begin{array}{c}\mathrm{S}, \\
\%\end{array}$ & $\begin{array}{c}\mathrm{N}, \\
\%\end{array}$ & $\begin{array}{c}\mathrm{C}, \\
\%\end{array}$ & $\begin{array}{c}\mathrm{H}, \\
\%\end{array}$ \\
\hline 1 & 2 & 3 & 4 & 5 & 6 & 7 & 8 & 9 \\
\hline $\begin{array}{l}\text { Coarse fraction after a } \\
\text { drum screener }\end{array}$ & 33 & 14 & 13 & 0.7 & 0.4 & 0.3 & 46.1 & 5.9 \\
\hline $\begin{array}{l}\text { Coarse fraction after a disc } \\
\text { screener }\end{array}$ & 34.7 & 15 & 13.2 & 0.95 & 0.2 & 0.2 & 4.8 & 7.1 \\
\hline
\end{tabular}

Table 3

Material properties used as an energy source for Broceni Cement Kiln

\begin{tabular}{|c|c|c|c|}
\hline Parameter & Unit & Value & Standards \\
\hline 1 & 2 & 3 & 4 \\
\hline Upper heating value UHV (dry basis) & $\mathrm{MJ} / \mathrm{kg}$ & $>22$ & CEN/TS 15400 \\
\hline Lower heating value LHV (as received) & $\mathrm{MJ} / \mathrm{kg}$ & $>16$ & CEN/TS 15400 \\
\hline Lower heating value LHV (dry basis) & $\mathrm{MJ} / \mathrm{kg}$ & $>20$ & CEN/TS 15400 \\
\hline Moisture (as received) & M.- $\%$ & $<25$ & CEN/TS 15414 \\
\hline Ash content (dry basis) & M.-\% & $<15$ & $\begin{array}{l}\text { CEN/TS } 14775 \\
\text { CEN/TS } 15403\end{array}$ \\
\hline Sulphur (dry basis) & M.- $\%$ & $<1.0$ & CEN/TS 15408 \\
\hline Chlorine (dry basis) & M.- $\%$ & $<0.8$ & CEN/TS 15408 \\
\hline Particle size & $\mathrm{mm}$ & $50 \times 50 \times 5$ & CEN/TS15415 \\
\hline Bulk density (as received) & $\mathrm{t} / \mathrm{m}^{3}$ & $>0.180$ & \\
\hline
\end{tabular}

Table 4

The system of solid recovered fuel classification

\begin{tabular}{|c|c|c|c|c|c|c|c|}
\hline \multirow{2}{*}{ Classification characteristic } & \multirow{2}{*}{$\begin{array}{l}\text { Statistical } \\
\text { measure }\end{array}$} & \multirow{2}{*}{ Unit } & \multicolumn{5}{|c|}{ Classes } \\
\hline & & & 1 & 2 & 3 & 4 & 5 \\
\hline 1 & 2 & 3 & 4 & 5 & 6 & 7 & 8 \\
\hline Net calorific value (NCV) & Mean & $\mathrm{MJ} / \mathrm{kg}$ & $\geq 25$ & $\geq 20$ & $\geq 15$ & $\geq 10$ & $\geq 3$ \\
\hline Chlorine $(\mathrm{Cl})$ & Mean & $\%$ & $\leq 0.2$ & $\leq 0.6$ & $\leq 1.0$ & $\leq 1.5$ & $\leq 3$ \\
\hline Mercury (Hg) & $\begin{array}{c}\text { Median } \\
\text { 80th percentile }\end{array}$ & $\begin{array}{l}\mathrm{Mg} / \mathrm{MJ} \\
\mathrm{Mg} / \mathrm{MJ}\end{array}$ & $\begin{array}{l}\leq 0.02 \\
\leq 0.04\end{array}$ & $\begin{array}{l}\leq 0.03 \\
\leq 0.06\end{array}$ & $\begin{array}{l}\leq 0.08 \\
\leq 0.16\end{array}$ & $\begin{array}{l}\leq 0.15 \\
\leq 0.30\end{array}$ & $\begin{array}{l}\leq 0.50 \\
\leq 1.00\end{array}$ \\
\hline
\end{tabular}




\section{Table 5}

Chemical content of ash for coarse fractions after screeners

\begin{tabular}{|c|c|c|c|}
\hline Element & Unit & $\begin{array}{l}\text { Mean values } \\
\text { of the coarse } \\
\text { fraction after a } \\
\text { disc screener }\end{array}$ & $\begin{array}{l}\text { Mean values } \\
\text { of the coarse } \\
\text { fraction after a } \\
\text { drum screener }\end{array}$ \\
\hline 1 & 2 & 3 & 4 \\
\hline $\mathrm{Hg}$ & $\mathrm{mg} \mathrm{kg}^{-1}$ & 0.495 & 0.40 \\
\hline $\mathrm{Cd}$ & $\mathrm{mg} \mathrm{kg}^{-1}$ & 0.82 & 0.66 \\
\hline $\mathrm{Tl}$ & $\mathrm{mg} \mathrm{kg}^{-1}$ & 0.34 & 0.26 \\
\hline $\mathrm{Br}$ & M.-\% & 0.008 & 0.002 \\
\hline I & M.-\% & 0.0008 & 0.001 \\
\hline $\mathrm{Sb}$ & $\mathrm{mg} \mathrm{kg}^{-1}$ & 8.62 & 2.90 \\
\hline As & $\mathrm{mg} \mathrm{kg}^{-1}$ & 0.58 & 0.40 \\
\hline $\mathrm{Cr}$ & $\mathrm{mg} \mathrm{kg}^{-1}$ & 13.37 & 23.76 \\
\hline Co & $\mathrm{mg} \mathrm{kg}^{-1}$ & 6.02 & 6.60 \\
\hline $\mathrm{Cu}$ & $\mathrm{mg} \mathrm{kg}^{-1}$ & 37.87 & 26.4 \\
\hline $\mathrm{Pb}$ & $\mathrm{mg} \mathrm{kg}^{-1}$ & 21.46 & 9.24 \\
\hline $\mathrm{Mn}$ & $\mathrm{mg} \mathrm{kg}^{-1}$ & 129.87 & 136 \\
\hline $\mathrm{Ni}$ & $\mathrm{mg} \mathrm{kg}^{-1}$ & 9.79 & 5.28 \\
\hline Sn & $\mathrm{mg} \mathrm{kg}^{-1}$ & 5.54 & 108 \\
\hline V & $\mathrm{mg} \mathrm{kg}^{-1}$ & 14.42 & 13.2 \\
\hline
\end{tabular}

\section{Characterisation of alternative fuel derived from municipal solid waste}

To improve the properties of sorted material according to the demands for usage as fuel for cement kiln, the mechanically sorted material (the coarse fraction after a drum screener) was mixed with manually sorted material ( 20\%). Figures a-d (Fig. 1) for six mixed samples (1-6) represent the data from the samples prepared by adding separately collected plastic and textiles and an output sample from the coarse fraction (7). The analyses of the main parameters indicate that the moisture content can be improved and the heat of combustion values can be increased by adding dry organic material.

The ash content meets the requirements of a high quality fuel only in some cases (examples 4 and 6).
The chlorine content corresponds to the limits for high quality fuel both in the coarse fraction and in the supplemented samples, except for sample 3 (exceeds the limit by $0.1 \%$ ).

Fig. 1

Comparison of six mixed samples (1-6) and the coarse fraction sample (7) compared with the requirements for alternative fuel for cement kiln
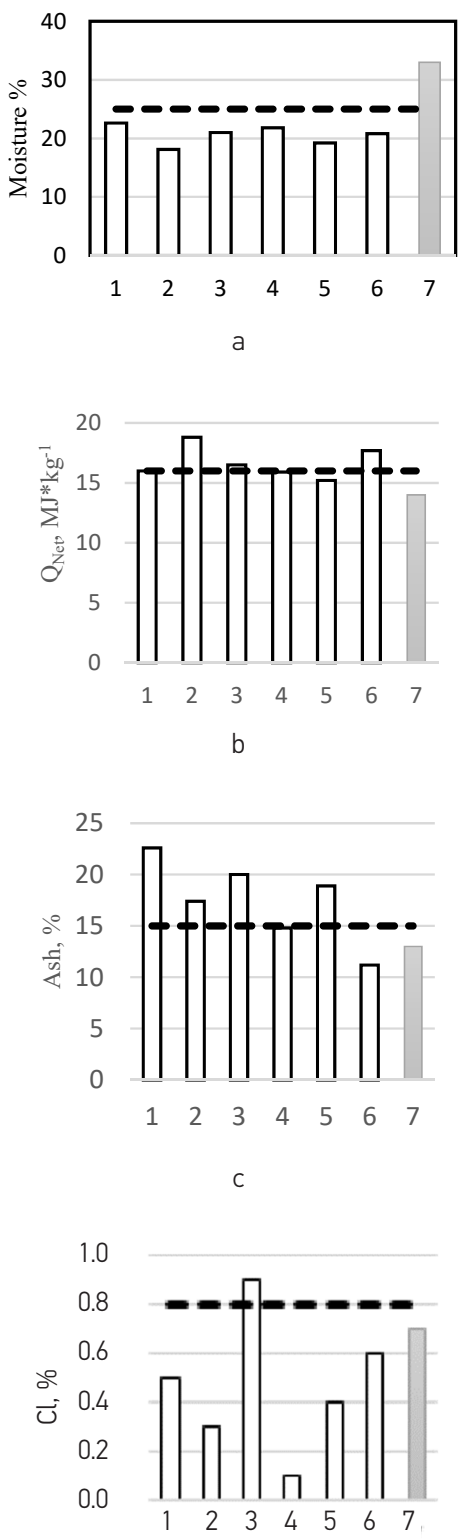

d 


\section{Conclusions}

1 The content of organic material in the mixed household waste can be raised by mechanical separation with disc or drum screeners. The coarse fraction after the separation process with a drum screener contains $25.8 \%$ of paper and cardboard $(10 \%$ in the mixed waste), $24.8 \%$ of plastic (11.5\% in the mixed waste), $12.8 \%$ of textile, rubber and leather $(4.4 \%$ in the mixed waste). The coarse fraction after the separation process with a disc screener contains $39.5 \%$ of paper and cardboard (6.1\% in the mixed waste), $38.7 \%$ of plastic $(10.1 \%$ in the mixed waste), and $10.6 \%$ of textile, rubber and leather ( $4.7 \%$ in the mixed waste).

2 The mean energetic parameters for pre-treated me-

\section{References}

Arina, D., Orupe, A. (2012) Characteristics of Mechanically Sorted Municipal Wastes and Their Suitability for Production of Refuse Derived Fuel. Environmental and Climate Technologies 8: 18-23.

Arina, D., Orupe, A. (2013) Comparison of Municipal Solid Waste Characteristics after Separation by Star and Drum Screen Systems. Proceedings of the International Scientific Conference Civil Engineering '13, 4(I): 318-322.

Beckmann, M., Pohl, M., Gebauer, K., Ncube, S., Spiegel, W., Müller, W. (2009) Characterisation of Refuse Derived Fuels in view of the corrosion potential, In: Proceedings of the International Conference on Incineration and Thermal Treatment Technologies - IT3, Cincinnati, USA, 18-22 May, 2009, pp. 69-80.

EC (European Commission) (2017a), Closing the loop - an EU action plan for the Circular Economy. Available at:http://ec.europa.eu/environment/circular-economy/implementation_report.pdf (accessed 24 December 2017).

EC (European Commission) (2017b), The role of waste-to-energy in the circular economy. Communication from the commission to the European Parliament, the Council, the European Economic and Social Committee and the Committee of the Regions, Available at: http://ec.europa.eu/environment/waste/ waste-to-energy.pdf (accessed 24 December 2017).

EPRS (European Parliamentary Research Service) Circular economy package, Four legislative proposals on waste, Jan- chanically sorted municipal waste respond to the limits stated for Class 3 of SRF. They are not available for cement kilns as the content of moisture is too high and the net calorific value is too low.

3 To improve the main characteristics of waste material after the separation of municipal waste on mechanical lines, manually sorted plastic and textile material can be added.

4 Biologically degradable waste separation at source and avoidance of hazardous materials containing chlorine and heavy materials are necessary to lower moisture, ash and chlorine content of potential fuel produced from waste. uary 2016 Available at: http://www.europarl.europa.eu/EPRS/ EPRS-Briefing-573936-Circular-economy-package-FINAL.pdf, 26.1.2017 (accessed 24 December 2017).

ERFO (European Recovered Fuel Organization) (2017), The role of SRF in a Circular Economy. Available at: https://www.erfo. info (accessed 24 December 2017).

Pohl, M., Bernhardt, D., Ncube, S., Beckmann, M., Spiegel, W., Müller, W. (2010) Diagnostic methods into the Corrosion Potential of Alternative Fuels i.e. Biomass and Refuse Derived Fuels. In: The Conference on Impact of Fuel Quality on Power Production and Environment, Saariselkä, Finland, 29 August-3 September 2010.

Rotter, V.S., Lehmann, A., Marzi, T., Möhle, E., Schingnitz, D., Hoffmann, G. (2011) New techniques for the characterization of refuse-derived fuels and solid recovered fuels, Waste Management \& Research 29(2): 229-236. https://doi. org/10.1177/0734242X10364210

Sharma, M., McBean, E. (2009) Strategy for use of alternative waste sort sizes for characterizing solid waste composition, Waste Management \& Research 27: 38-45. https://doi.org/10.1177/0734242X07082764

Vounatsos, P. (2012) Refuse Derived Fuels (RDF) Sampling and Analysis at the "EMAK" MBT Plant in Athens, Greece - Proposals for Process and Fuel Quality Optimization. In: Proceedings USB of the ISWA congress. 


\section{Energijos šaltinis iš komunalinių atliekų pagal ES veiksmo planą žiedinès ekonomikos kontekste}

\section{Arina, R. Bendere}

Fizikinès energetikos institutas, Latvija, LV-1006, Ryga, Krivu g. 11

Tyrimai rodo, kad komunalinių kietuju atlieku sudèties ir savybių pokyčiai koreliuoja su komunaliniu kietuju atlieku rūšies dydžiu ir tankiu, kad mechaninis išankstinis apdorojimas, iskaitant atskyrimą pagal svorị ir dydi, gali būti naudingas ruošiant iš atlieku gautą kuro (RDF) medžiagą ir kietą regeneruotą kurą (SRF), kuris naudojamas energijos išgavimui. Autoriai nustato atskiras komunaliniu atlieku frakcijos sudedamuju daliu parametrus (mažesnę šilumos vertę, drègmę, pelenu kieki, angli, azotą, vandenili, sierą, chlorą ir metalus) ir ivertina ju gyvybingumą alternatyvaus kuro gamybai.

Raktiniai žodžiai: atliekos energijos šaltinis, žiedinè ekonomika, komunalinės atliekos. 